\title{
Chief Executive Officers and their Boards: a Play of Power
}

\author{
Ndifreke Bassey Asuquo ${ }^{1} \&$ Osasu Obaretin ${ }^{2}$ \\ ${ }^{1}$ Nigerian Communications Satellite Limited, Nigeria \\ ${ }^{2}$ Department of Accounting, University of Benin, Benin City, Nigeria \\ Correspondence: Osasu Obaretin, Department of Accounting, University of Benin, Benin City, Nigeria. E-mail: \\ osasu.obaretin@uniben.edu
}

Received: February 21, 2019

Accepted: June 18, 2019

Online Published: June 24, 2019

doi:10.5430/bmr.v8n2p27

URL: https://doi.org/10.5430/bmr.v8n2p27

\begin{abstract}
This study is motivated by the need to understand conceptually issues in Chief Executive Officers dominance.

To achieve this objective, a library research design was employed to review and understand relevant concepts relating to Chief Executive Officers and boards. Issues relating to Chief Executive Officers dominance and rubbers stamp boards were also $\mathrm{x}$-rayed.

The paper concluded from the review that the influence of the Chief Executive Officer on the board can be condensed by reducing board dependency on the Chief Executive Officer while increasing Chief Executive Officer dependency on the board. Also, studies in this area of research are encouraged to provide insight into the effects of Chief Executive Officer-board interaction on organizational outcomes.
\end{abstract}

Keywords: chief executive officers, rubber stamp board, chief executive officers dominance

\section{Introduction}

The significant role played by Chief Executive Officers (CEOs) in driving corporate successes and at times their failures across the world have heightened research interest in this area of corporate governance studies. The successes of firms like Microsoft incorporated, the Dangote Group and Apple incorporated have been largely attributable to their CEOs (current or former)- Bill Gates, Aliko Dangote and Steve Jobs respectively. On the other hand, the collapses of well-known companies around the world including Nigeria can be traced to the significant roles their CEOs played in such failures despite the existence of internal corporate governance regulations and boards of directors in these companies. For instance, the collapse of Enron, an American based commodities, energy and service corporation was attributed to actions of the CEO, Jeff Skilling and the former CEO, Ken Lay who were keeping massive debts off the financial statement and disclosing fraudulent accounting information while in Worldcom, a telecommunications company, her CEO had unquestionable power over the company affairs and participated in accounting irregularities (Breeden, 2003).

In Nigeria, the roles played by the CEOs of most distressed and bailed out banks between 2009 and 2010 are quite illustrative. The CEO of the then Oceanic bank, Cecilia Ibru is said to have controlled over thirty-five per cent of the bank through Special Purpose Vehicles (SPVs) set up to borrow customers deposits for stock price manipulations and other personal gains (Uwuigbe, 2011) while the MD/CEO of the then Intercontinental Bank Plc, Dr Erastus Akingbola removed from office by the Central Bank of Nigeria (CBN) was arrested and accused by the "Economic and Financial Crimes Commission (EFCC) of insider abuse, theft, manipulation of the company's shares and other economic crimes running into billions of naira" (The Nation as cited in Okoye, 2015).

In a reaction to this menace in the banking sector, the then CBN Governor, Sanusi Lamido Sanusi opined that some of the banks' chairmen and CEOs were seen to exercise overbearing influence on the board and that some boards lacked independence. It was also reported that some board members were found securing credits without adequate collateral which made it impossible for them to enshrine sound corporate governance practices in the banks and to also challenge the executives (Uwuigbe, 2011).

From the foregoing, it goes to show that most boards are not capable of performing their role in the corporate governance mechanism, being the overseeing of activities of the total management team (TMT), including the CEO due to their compromise as well as the dominant and overbearing influence of their CEOs. Thus, bringing to need to examine the influence of CEOs on their board. 


\subsection{Objective of the Study}

This paper will conceptually examine the power tussle between CEOs and their board. The being desk research, relevant materials were gathered from journal articles, internet sources and so on.

\section{Literature Review}

\subsection{Chief Executive Officer (CEO)}

\subsubsection{Who is a CEO?}

Peter Drucker in his unfinished draft saw the CEO as the only person in the firm who can perceive the outside from an enterprise level (Nithiyanandan, n.d.). The CEO is the head of the executive management team of any organisation and pilots the affairs of such organisation. She/he is also a member of the board of directors of companies.

The major rationale for studying the CEO is due to the central and pivoting role he/she plays in the corporate governance mechanism of any organisation. According to Barclift (2011) CEOs are seen as the fulcrum of corporate governance. Stressing further, Johnson and Yi (2015) maintained that influential CEOs can manipulate the very corporate governance that imposes constraints on their actions by using managerial powers.

\subsubsection{Role of a CEO}

The CEO is one who is often held accountable for the failure or success of an organisation The main component of his/her job description include strategy setting and organisational direction; modelling and formulating the organisational culture, values and behaviour; building and leading the senior executive team; and allocating capital to the company's priorities (Robbins, n.d.). These job roles of the CEO according to Robbins cannot be delegated, though he/she may get inputs in these areas.

The setting of strategy and vision is seen as the CEO's main duty. Though the senior management team can help develop a strategy and the board can endorse, advice or ask the CEO to revise a business strategy, it is the CEO who ultimately determines the company direction. This may be in the areas of which market to enter, company's product line, how the company can differentiate self from her competitors and so on.

The CEO is also expected to model and set a company's culture, values and behaviour. Robbins posited that it is the organizational culture that will determine the calibre of persons working in that organisation. For instance, a lousy organisation will drive away high performers while a great working environment can draw and retain the very best manpower. Organisational culture can be formulated in a number of ways and it is the CEO who sets the tone. The CEO's every action or inaction sends the cultural signals. Values tell how the company intends to reach its vision as it spells out what is acceptable behaviour. The CEO is said to convey values through his/her actions or reactions to others.

The third responsibility of the CEO has to do with building and leading the senior executive team. The CEO is a leader and is responsible for leading, hiring and firing the senior management team who in-turn manages the rest of the organisation. Lastly, it is the duty of the CEO to allocate the scarce resource (capital) to the company's priorities. $\mathrm{He} / \mathrm{She}$ funds projects that support the strategy. He/She manages the firm's capital and his /her decisions often determine the company's financial fate.

\subsubsection{Understanding Board of Directors}

According to Asuquo and Amade (2018), "the board of directors is the highest governing authority within a company as clearly stated by codes of corporate governance of companies in operation around the world". Also, Pathan (2009) considers the board as the apex body of a company's internal governance system. The board of directors usually consists of executive and non-executive directors. The executive directors are the full-time employees of the company. While the non-executive directors are not employees of the company. They are not involved in the day-to-day running of the company. These non-executive directors usually receive a flat fee for their services. Boards could be one-tier or two-tier board; with the one-tier board having a single board performing both supervisory and managerial responsibilities. The two-tier board distinguishes "a management board and a supervisory board with no overlapping membership between them; with the management board of a lower level than the supervisory board" (Ogebechie, 2012).

Ogbechie also sums the board's role into three namely control role, service or advisory role and strategic role. The controlling role is otherwise called the oversight or monitoring role of the board over the CEO and top management. 
The service role entails the advisory role of the board. It involves offering the CEO and top management with expert advice. Lastly, the strategic role covers the area of defining, selecting and implementing strategies for the company.

\subsection{CEOs and Boards}

\subsubsection{CEOs in Relation to Rubber Stamp Boards}

Owing to corporate collapses both locally and internationally; there have been contentions amongst scholars and other stakeholders that most boards are merely rubber stamp boards. Rissi and Carter (2016) defined rubber stamp boards as boards that tend to adopt a hands-off approach to their duties and simply assent almost everything put in front of them by management without robustly involved in deliberation and debate. This approach is said to be quite detrimental to the firm and the directors. More so, when rubber stamp boards approve decisions of management without serious deliberation, they surrender the company and lose sight of what is actually happening beneath the surface.

Kemp (2006) contended that the "evolution of boards from managerial rubber stamps to active and independent monitors is yet to begin in some corporations". This is because as stated by Tosi, Shen and Gentry (2003) most board members are not interested in the CEO's action as long as they are able to hold on to their position on the board. For instance, boards may focus more on advising and reviewing steps in the strategy formulation process rather than initiating strategy (Kemp, 2006).

The causes of weak or rubber stamp boards can be linked to what happens inside most boardrooms. According to Kemp, most board members are discouraged from openly challenging or questioning the CEO's performance by the norms of polite board room behaviour and the pervasive presence of insiders. Also, directors are said to have a strong dependence on the CEO, as many posses far greater information and knowledge about the business than any director could possess. Lastly, CEOs rather than board members largely control the agenda of the meeting and discussion process, even where there is a board chairman.

Commenting on how to combat rubber-stamp board, Rissi and Carter (2016), proffered some remedies to include educating directors. This entails making board members understand their fiduciary duties and potential liability if they fail to fulfil them. Also, directors should be encouraged to implement and enforce appropriate policies and procedures. Like CEOs' authority being limited through policies and procedures that demand them to operate within the confines of approved budgets, financial procedures, compensation policies and so on. There should also be policies and procedures that define the scope of authority delegated to officers and committees. Directors, especially outside directors should be made to feel a personal connection to the organisation in order to be more active.

\subsection{The Issue of CEO Dominance}

The question of whether CEOs are larger than their board's centres on CEO's dominance or power over the board. According to Emerson (1962)," a power relationship will always arise between two interacting agencies, whether it is between two individuals, two groups or an individual and a group". This is the case of the CEO and the board. Ideally, the existence of a board of directors is to make for appropriate checks and balances within the corporate structure of an organization as the CEO is supposed to be accountable to the board while the board is to be accountable to the shareholders. However, Kelley (2002) posits that this built-in checks and balances (corporate governance) have failed to owe to an inordinate amount of the real power concentrated in the CEO, while most boards seem willing to let the CEO be in charge and have abdicated their authority and responsibilities. This situation is what Barclift (2011) called CEO dominance or CEO centrality, describing the capacity of the CEO to exercise his will on decision making.

Zhang, Fadil, and Baynard (2013) posit that using Emerson's 1962 power dependency framework, one can understand the relationship between the board and the CEO. The board is said to have power over the CEO to the degree that the board has the power to address the CEO's critical needs which no other party can satisfy. Likewise, the CEO has power over the board to the degree that the CEO has the ability to address the board's critical needs, which cannot be met by other parties. Thus, the board's power over the CEO is analysed through CEO dependency issues, which are what the CEO needs from the board to include evaluating CEO's performance, deciding on CEO's compensation plan and approving the strategic proposal submitted by CEO. In the same vein, CEO's power over the board is analyzed via board dependency issues which are what the board needs from the CEO. One key component of the board's needs as identified by Zhang et al. is firm-specific information, which is asymmetrically distributed between the board and the CEO.

In sum, Zhang et al. (2013) posited that the board's power over the CEO can mainly be expressed symbolically, that is, via actions like providing explanations, justifications and mission statements. Symbolic actions are mainly 
expressed but not necessarily actually performed. The rationale for this is that the board faces a high level of uncertainty in handling CEO dependency issues which are multiple factor based decisions. For instance, in deciding CEO's compensation plan, the board must consider whether the compensation should be based on firm's performance, compensation pressure from the external labour market, motivational, recruitment and retention reasons, matching other board members' earning and so on. Whereas, in practice, the CEO faces a low level of uncertainty in dealing with board dependency issues which are providing firm-specific information to the board. Thus, the CEO's power over the board on issues relating to firm-specific information provision is unlikely to be on a symbolic level.

Specifically, one of the ways by which CEO's dominance over the board can be appreciated is via his ability to control the flow of information provided to the board. According to Barclift (2011), CEOs manage the corporate governance process by selecting the information the board reviews and approves at board meetings. Such control of the flow of information to the board will not only result in information blockage for directors but also results in a less-than-informed decision by the board.

Another possible way CEOs may seem larger than their boards is that they often influence the nomination of those that will serve on the board as posited by Barclift. Consequently, directors selected by a CEO to serve on board are often indebted to the CEO. Moreso, even in situations where CEOs are to be hired, boards typically seek for CEOs with dynamic, strong-willed personality, a trait, which a study by Langevoort (as cited in Barclift) revealed may lead to the weakening of boards' corporate governance power.

Lastly, CEOs exert influence over the board and management by sheer force of personality and resultant over-confidence (Barclift, 2011). The charisma, confidence and personality of the CEO are such that will create an environment where he receives too little criticism and too much affirmation. Barclift further maintained that over-confidence fosters an environment where "the board gives too much deference to the CEO". More so, since cohesive groups identify with a strong leader and tend to comply with the leader's wishes, the boards being highly cohesive and homogeneous group will rely on social norms which limit their effectiveness in detecting undesirable behaviour of the CEO. Relatively, being too assertive in the boardroom may be perceived as undermining the board as a group.

However, some of the ways to improve board powers and curtail the influence of a dominant CEO include making for increased board control over the CEO dependency issues like CEO performance evaluation, compensation plan and approval of CEO's strategic plan; and reducing board information dependency on the CEO (Zhang et al.,2013). This is regarded as one of the most effective ways to improve the board's power. This can be achieved by ensuring that the board can seek for firm-specific information from other alternative sources like the Chief Financial Officer (CFO), and marketing director to supplement information provided by the CEO. As an addendum, while choosing directors to the board, efforts should be made to include a director that is experienced in information research. This is because such a director understands how best to find, sift and interpret critical information for the firm. Lastly, boards should deliberately endeavour to control meeting agenda's to strengthen the quality of deliberation and boards' decision making (Kelley, 2

\section{Conclusion and Recommendations}

This paper conceptually examined the issue of CEO dominance. Aside the CEO being a prominent and often influential member of the board, he/she is ideally supposed to be accountable to the board as mandated by the internal corporate governance mechanism of any organisation. However, this is not always the case in most organisations across the world today. Curbing CEOs' dominance will involve amongst other measures as highlighted in the paper to increase board's control over the CEO dependency issues like CEO performance evaluation, compensation plan and so on.

It is hoped that corporate governance institutions across the world would institute guidelines that will strengthen corporate boards and wane the influence of dominant CEOs by incorporating some of the recommendations of this paper. Also, research into this area of corporate governance should be encouraged by accounting and management sciences scholars.

\section{References}

Asuquo, N. B \& Amede, F.O. (2018). How do boards moderate the powers of powerful CEOs? Accounting and Taxation Review. Retrieved from www.atreview.org

Barclift, Z. (2011). Corporate governance and CEO dominance. Washburn Law Journal, 50, 611-634. 
Breeden, R. C. (2003). Restoring trust: Report to the Honourable Jed S. Rakoff, the United States District Court for the Southern District of New York, on corporate governance for the future of MCI, Inc. Inc. Corporate Monitor, 117.

Emerson, R. M. (1962). Power-dependence relations. American Sociological Review, 12(1), 31-41. https://doi.org/10.2307/2089716

Johnson, W. \& Yi, S. (2015). Powerful CEOs and corporate governance: Evidence from an analysis of CEO and director turnover after fraud. Asia-Pacific Journal of Financial Studies, 43, 838-872. https://doi.org/10.1111/ajfs.12074

Kemp, S. (2006). In the driver's seat or rubber stamp? Management Decision, 44(1), 56-73. https://doi.org/10.1108/00251740610641463

Kelley, R. E. (2002). CEO power threatens board checks and balances. NACD Directorship, 28(10), 15-17

Nithiyanandan, L. (n.d.). Are CEOs expected to be magician? BTI Consultants. Retrieved from www.kellyservices.co.nz/NZ/kelly-services-CEO-magicians-white paper

Ogbechie, C. (2012). Key determinants of effective boards of director: Evidence from Nigeria (Doctoral thesis) Brunel Business School, Brunel University.

Okoye, N. (2015). Barriers to effective corporate governance reforms: Corruption and the peculiar case of Nigeria. In S. Boubaker \& D. Nguyen (Eds.), Corporate governance and corporate social responsibility: Emerging markets focus. Singapore: World Scientific Publishing Co. Ptc. Ltd. https://doi.org/10.1142/9789814520386_0005

Pathan, S. (2009). Strong boards, CEO power and bank risk-taking. Journal of Banking and Finance, 33(7), 1340-1350. https://doi.org/10.1016/j.jbankfin.2009.02.001

Robbins, S. (n.d.). What do CEOs do? A CEO job description. Retrieved from www.steverobbins.com/articles/ceojob/

Rissi, A. \& Carter, E. (2016). How to combat the rubber stamp board? Retrieved from http://charitylawyerblog.com/2016/12/26/how-to-combat-the-rubber-stamp-board/

Securities and Exchange Commission. (2011). Code of corporate governance for public companies in Nigeria. Retrieved from http://www.sec.gov.ng/code-of-corporate-governance-html

Shen, W. (2005). Improve board effectiveness: The need for incentives. British Journal of Management, 16, 81-89. https://doi.org/10.1111/j.1467-8551.2005.00449.x

Tosi, H. I., Shen, W., \& Gentry, R. J. (2003). Why outsiders on boards can't solve the corporate governance problem. Organisational Dynamics, 32(2), 180-192. https://doi.org/10.1016/S0090-2616(03)00017-2

Uwuigbe, O. R. (2011). Corporate governance and financial performance of banks: A study of listed banks in Nigeria (Doctoral dissertation, Covenant University, Ota, Ogun State). Retrieved from eprints.covenantuniversity.edu.ng/id/file/18322

Zhang, F., Fadil, P., \& Baynard, C. (2013). Understanding the board-CEO power dependency perspective under symbolic management. Competitive Review, 25(1), 50-73. https://doi.org/10.1108/CR-05-2013-0051 